\title{
Economic Records in Chinese
}

Kozlov's Khara-Khoto expedition (1908-1909) brought to light large quantities of social documents written not only in Tangut, but also in Chinese, some of which are also economic records of Western Xia. These manuscripts are mostly published in the Chinese sections of the Russian Collection of Khara-Khoto Manuscripts. Additionally, a small number of Tangut-era Chinese economic records have been found in the British holdings first discovered by Stein. Most of these texts written in Chinese characters are miscellaneous pages and remnant volumes, which have so far been compiled and examined by experts. In order to present a full account of Tangut economic records, this chapter introduces readers to the Chinese manuscripts which may be studied comparatively with the Tangut texts of similar types and dated to the same period.

\section{Markets and Materials}

In the eras of the Northern and Southern Song, Liao, Xia, and Jin dynasties, up to the Mongol Yuan dynasty, border-markets functioned as exchange posts that connected the flow of goods and materials across territories of various ethnic regimes. Certain appointed officials presided over commercial activities in these trade markets. With the exception of government-controlled transactions, private merchants had to pay taxes in exchange for an official certificate as a token of approval to trade. Indeed, the Chinese documents provide important information on these trade markets.

\subsection{Market Records}

The twelve pieces of market records are written on the cover pages of the Tangut woodblock print Mahāvaipulya Buddhāvatamsaka Sütra. ${ }^{1}$ When used as a layering paper, the document was cut at the top and the bottom, and thus remains a broken manuscript.

\subsubsection{Format and Content}

Take Russian manuscript Инв. No. 307, a document of an official in the southern market, as an example. It is $13.2 \times 35 \mathrm{~cm}$, and the two sides-both documents

1 Russian Collection of Khara-Khoto Manuscripts, vol. 6, pp. 279-286. 


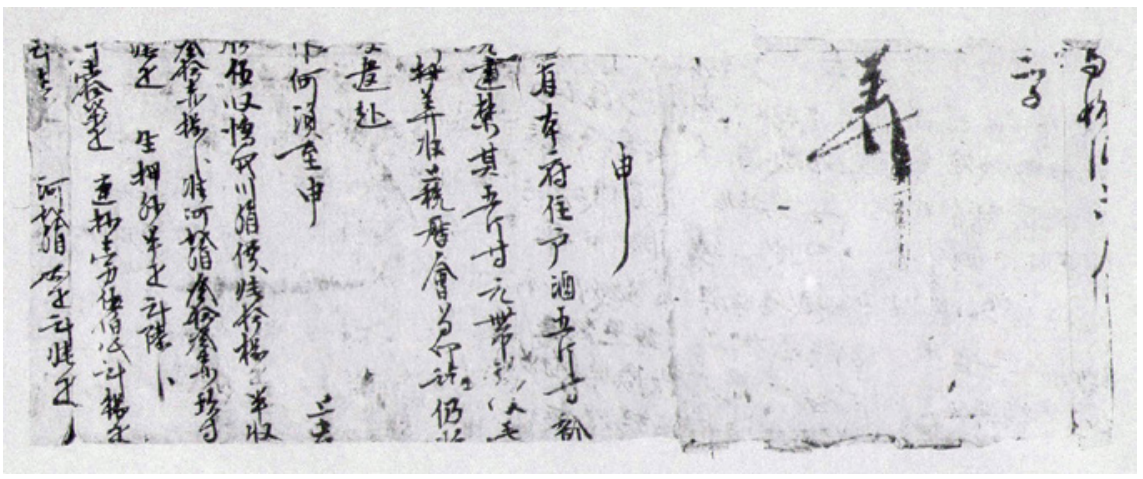

FIGURE 209 Инв. No. 307: application filed by the intendent of the southern market, to the silver medal official, concerning the settlement and tax related to the purchase of goods at government-fixed prices, including five jin of alcohol, by residents of this region

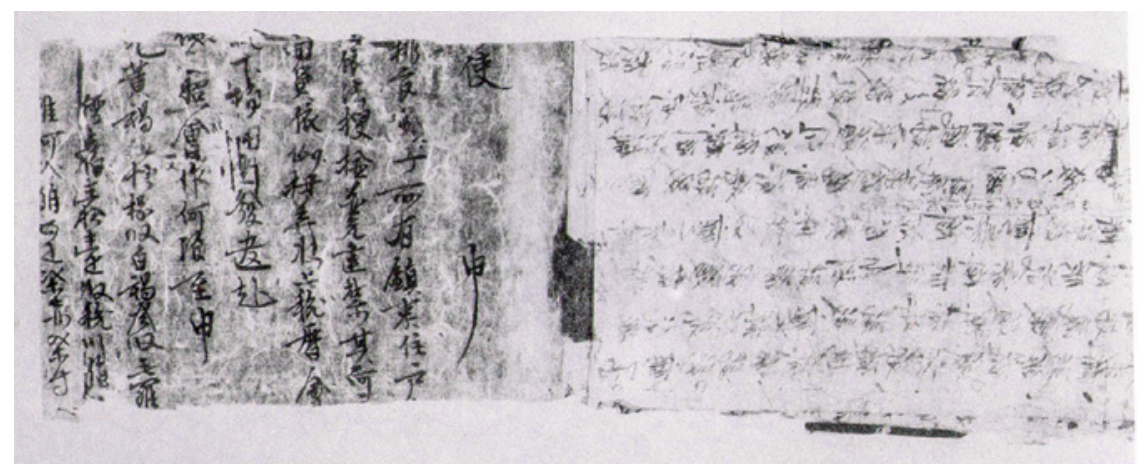

FIGURE 210 Инв. No. 307: application filed by the intendent of the southern market to the silver medal official, concerning the settlement and taxes related to the purchase of goods at government-fixed prices by certain residents in Zhendong

Note: $\mathrm{TN}$ : It was a common practice in the times of Northern Song that the government would fix commodity prices, and designate individuals or associations to purchase the goods en masse. It seems that either the 'purchase' here is in the general sense, or that the Tanguts also practiced price-fixing and government purchase. The fact that the Market Intendents had to report to the Silver-Medal Official speaks somewhat to the official nature of the transaction. But it remains entirely possible that the purchase is normal, and that the reporting is a procedural requirement. 
of the same type-are patched together. One side has 14 lines of Chinese, with the top and bottom cut, and the other has nine lines, also in Chinese. ${ }^{2}$

Sun Jimin and other scholars have named the two pages of the document "Application Filed by the Intendent of the Southern Market, to the Silver Medal Official, concerning the Settlement and Tax related to the Purchase of Goods at Government-fixed Prices, including Five jin of Alcohol, by Residents of this Region" and "Application Filed by the Intendent of the Southern Market to the Silver Medal Official, concerning the Settlement and Taxes related to the Purchase of Goods at Government-Fixed Prices by Certain Residents in Zhendong." The following is a literal translation:

$(1)$

... Gao

... calculate

... report

... Resident in the same district, alcohol 5 jin ...

... No violation of prohibitions, 5 jin carried cloth, ${ }^{3}$ fur ...

... calculate, raise the taxes, to be stamped, still ...

... distribute, to

... must be reported to higher offices ...

...5 duan, fixed-price purchase of Sichuan silk, price $48 \mathrm{pi}^{4} \&$ half, received ...

...30 chi 8 fen, standard Hebei silk 33 chi 9 cun ...

...4 pi, raw yarn half a $p i$, counted $6 \mathrm{fen}$.

...17 pi, lianchao ${ }^{5} 10500$ mace, counted 8 pi ...

... counted 1 pi, Hebei silk 2 pi, counted 4 pi ...

...

$(2)$

...

... Intendent application

... head officer: all residential households in Zhendong ...

... search according to law, no violation of prohibition, its ...

2 Russian Collection of Khara-Khoto Manuscripts, vol. 6, p. 279.

3 TN: "self-carried" (Chinese: 原带) refers to residents of the same district bringing their own cloth for export.

$4 \mathrm{TN}$ : 疋 is the equivalent of 匹, a unit of cloth. See Book of Han (漢書), "Biography of Shusun Tong” (叔孫通傳), “乃賜通帛二十㱜, 衣一襲, 拜為博士” etc.

$5 \mathrm{TN}$ : 連抄 is a type of paper. 
... returned goods to be counted by the standard of precedents, registered on tax accounts ...

... The following items $\square \square$ to distribute

... to conduct what type of reference, must apply

... yellow cloth 58 duan, white cloth 3 duan, fur cloth ...

... price 311 pi, raise tax on Sichuan Silk ...

... Standard Hebei silk 2 pi 7 chi ${ }^{6} 7$ cun ...

Similar manuscripts include Инв. No. 308, 313, 315 (1), 315 (2), 315 (3), 316, 347 , $351,35^{2} \mathrm{~A}, 35^{2} \mathrm{~B}, 353$, and 354 . These records of market transactions offer a glimpse into the commercial activities across the bounds of the Tangut Empire and Central Plains, and refer to a wide range of commodities. Amongst them, silk products included Sichuan fine silk, Hebei fine silk, hansha silk, Sichuan colour-patterned silk, small coloured silk fabric (shixie), ${ }^{7}$ small aura-silk (yunxie), large silky linen, small patterned silk fabric, medium flora-patterned gauze, small thin silk, purple thin silk, yellow light linen, and purple light linen. Fur products included fur cloths (pinhe), yellow fur cloth (huanghe), white fur cloth (baihe), fur yarn (for weaving clothes), fine leather, white ribbon, and otter fur. Condiments included ginger, peppers, honey, tea, etc. Other commonly used commodities included papers, brushes, ink, and 'deer arrows.'

One could easily tell that the lion's share of trade in the market fell within the exchanges of silk, cloth, and fur. Manuscript Инв. No. 308 mentions, "[2]9 duan, white cloth 6 duan, purchase of Sichuan [silk] at fixed price"; Инв. No. 313 notes, "yellow cloth 16 duan, purchase of Sichuan silk at fixed price"; Инв. No. 353 records, "cloth 40 duan, white cloth 4 duan, purchase of Sichuan [silk] at fixed price." Clearly, the Tanguts traded their own fur cloth products for Sichuan and Hebei silk in these border markets. The Tanguts also imported sauces and spices as well as stationaries from Song; goods included everything from ginger, peppers, and tea to brush, ink, and paper. ${ }^{9}$

Chinese historical archives have documented Tangut trade with Song, Liao, and Jin along the imperial frontiers. In the Fourth Year of Song's Jingde reign (1007), the Song court approved King Deming's request to establish trade posts in Bao'an, commencing the history of large-scale Song-Xia bilateral trade. The Song empire "traded silk fabrics and coloured linens for camels and horses,

$6 \mathrm{TN}$ : 赤 $=$ 尺.

7 TN: Chinese: 絁缬.

8 TN: Beyond the obvious literal meaning, the reference to 鹿射箭 remains unclear.

9 Du Jianlu and Shi Jinbo, 2012, pp. 22-3o. 
cattle and sheep, jade and fur carpets, as well as liquorice plants (gancao); Chinese perfume, spices and medical herbs, ceramics, ginger and cinnamon, and other goods were exchanged for mila amber, sheqi musk, fur and hemp shirts, goat-antelope horns, the mineral sal ammoniac, bupleurum herbs, cistanche, safflower, and plume." As these joint market sessions came to an end, the two governments "let the people free to trade amongst themselves." ${ }^{\text {"10 }}$ In the Ninth Year of Heavenly Endowed Rituals and Laws and Extended Bliss (天授禮法延祚) in Western Xia (1046), the Song and Xia negotiated a peace settlement. Part of the peace terms were agreements to revive the market in the Bao'an Military District (close to modern-day Zhidan county of Shaanxi province) and to find new ones near the Gaoping Fortresses in the Zhenrong Military District (present-day Guyuan, Ningxia). After the imperial court of the Song Dynasty relocated to the south, the Jin Dynasty emerged as the new main trading partner with Western Xia, after gaining firm ground as a power in the Central Plains. In the second year of Daqing in Western Xia (1141), the Xizong Emperor of Jin, in response to a formal request from Emperor Renzong of Xia, agreed to set up markets along the northwestern Yunzhong area:"1 Guoyaodai, Shang Shileng Po, ${ }^{12}$ Tiande, Yunnei, and Yinweng. This region was once a busy trading zone for the Liao and Xia. Besides renewing Khitan-era infrastructures, the Tanguts and Jurchens expanded the scope of their commercial exchange. In around the same period, the Tanguts and Jurchens also established bilateral markets in Lanzhou, Bao'an, and Suide.

To secure robust control over foreign trade, both the Song and Jin Empires established markets, overseen by senior officials and special agencies, just slightly within their own border lines. Western Xia, in particular, designated managers and officers of the markets to be in charge of overseeing commercial activities. ${ }^{13}$ There was, in addition, an officer in charge of tax collection. The standard policy was to "raise a limited amount of taxes from Han [merchants] from the imperial region [the Song Dynasty]; raise the normal amount of taxes on Fan merchants in the western territories."14 This state of affairs remained

$10 \quad$ History of Song, Bk. 186. "On Food and Trade" II. 8, "Laws of Bilateral Trade."

11 TN: Yunzhong (雲中) refers to the area of Yunzhou or Yunzhong county (present-day Datong, Shanxi), an administrative region that Song inherited from Tang. The Khitans, however, referred to it as Datongfu.

12 TN: My understanding is that 上石楞坡 is located somewhere near the city of Fengzhen

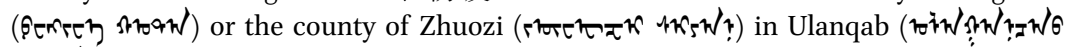
stroat) in south-central Inner Mongolia.

13 Zizhi Tongjian, Bk. 436, 2nd Year of Jiayou in Emperor Renzong's Reign (1057), second month, Renxu.

14 Wen, Yanbo. Lugong Wenji [潞公文集], photocopy of the Siku Quanshu edition [四庫全 書本], see printed edition by Taipei: Taiwan Commercial Press, 1983; (明嘉靖五刻本, 傅 
more or less the same after the Jurchens put an end to the Northern Song imperium. Some of the aforementioned Chinese market records provide detailed accounts of Tangut "levies on Fan merchants."

These documents from Tangut markets make it clear that cross-border trade was conducted under the command and supervision of the Market Officer. Upon the closing of a deal, the Market Officer issued a "reference" document and reported to higher administrative offices in the relevant departments. These official "reference documents" were submitted in the names of the Market Officers, signed at the top by the "Intendent of the Market" or the "Intendent of the Southern Market," followed by the Chinese character “申” and "Silver-Pai Head Officer" or "Head Officer."15 Whilst taxing Tangut merchants, the officials conducted inspections on the goods and commodities and required the submission of information including addresses, names, types of goods carried, and whether any resupplied cargo contained goods prohibited from transaction. Moreover, the taxes were "counted and raised, officiated with a stamp" and "immediately dispatched for distribution." The second half of the document records the purchase of goods at fixed prices and the tax receipts, followed by the year and printed signatures.

The first half of the document ends with the expression, "In prostration, humbly requesting a reference document; it is necessary to report to higher offices" (Chinese: 伏乞照會作何須至申), which not only points out the nature and purpose of the document but also reflects the standard format of reference notices of the Song and Xia period.

\subsubsection{Locations of Inter-State Trade Markets in the \\ Economic Documents}

The largest number of market records appear to have originated from the Zhenyi county and the Xiliangfu. The Tanguts established an administrative system of prefectures and commandries. The Su Prefecture (Jiuquan, Gansu), for example, corresponds to Fanhe Commandry, and the Gan prefecture (Zhangye, Gansu) is equivalent to Zhenyi Commandry. ${ }^{16}$ This piece of information had been known for a long time solely in the Book of Western Xia (Xixia Shushi), without any labels or notations of original sources. Therefore, it has been subject to the rightful suspicion of historians. Later, the name "Zhenyi

\footnotetext{
增湘校本; edited by 四川大學古籍整理研究所) Beijing: Xianzhuang Book Company, 2004; (叢書集成續編. 集部. 別集類 101) Shanghai: Shanghai Shudian, 1994. Bk. 19, “Zou Xixia Shi Zhao Shi" [奏西夏誓詔事].

15 TN: I have translated 銀牌 as Silver Pai, Paiza, or more loosely, tablets, tokens, and medals. These are tablets signaling rank and status, power and privilege.

16 Xixia Shushi, Ch. 12.
} 
Commandary" was discovered on a stele inscription in Zhangye, which provided a second layer of historical evidence. Now, with the explicit reference to Zhenyi in market records, the existence of this administrative unit in Western Xia may be properly established beyond doubt.

Xiliangfu is another name for the Liang prefecture (today, the city of Wuwei, Gansu). The government of Xiliangfu was first established in the early Song period, but it later fell to Tibetan invaders. In the aftermath of the Tangut conquest of the Hexi Corridor, Western Xia inherited the title of Xiliang, though sometimes also referred to the prefecture simply as Liangzhou. Such is the expression as it appears in the Chinese text of the renowned "Inscription of the Renovated Liangzhou Pagoda."

No reference to markets in the Hexi Corridor is found in conventional sources such as historical chronicles. The Liangzhou market records mentioned above could fill in this historical gap. Manuscripts Инв. No. 347 and Инв. No. $35^{2} \mathrm{~B}$ end with the signature "by the Intendent of the Market, the Market Officer of Xiliang, and the Public Notary of Records," which makes clear that the official manager of the market (Chinese: 拘榷) exercises jurisdiction over the Xiliang territory, and also assumes responsibility as the Public Notary, or Record Keeper (簽判). ${ }^{17}$ Both positions are related to the government of Xiliang.

The next question is whether the "Southern Market" referred to in manuscripts Инв. No. 315 and Инв. No. 354 are related to the "Southern Realm" administration as mentioned in the Laws of Heavenly Prosperity. Amongst the many military supervisory districts of Western Xia, there is a "Military Supervisory District of the Southern Realm," which should have been located in the Prefecture of Liang. The Tangut-Chinese bilingual inscription of the Liangzhou Stele matches the "Southern Realm" with the "Right Compartment."18 Therefore, in most if not all likelihood, the market of Liangzhou might be none other than the celebrated Market of Lanzhou. Historical chronicles record that in the early period of Western Xia, the Tanguts traded with the Song Empire near the Gaoping Fortresses in the Bao'an and Zhenrong military districts. In

17 TN: 簽書判官廳公事, see Chen, Yanxiao [陳岩肖]. Geng Xi Shi Hua [庚溪詩話] Bk. 1. “英宗朝, 自鳳翔簽判滿任, 慾以唐故事召入翰林”; Wu, Zimu [吳自牧]. Meng Liang Lu [夢梁錄], “Shiren Fu Dianshi Changming” [士人赴殿試唱名], “其狀元官授承事 郎, 職除上郡簽判, 榜眼授承奉郎, 探花授承務郎, 職注中郡或下郡簽判”; Gao Cheng [高承]. Shiwu Jiyuan [事物紀原] on 簽判 and Wenxian Tongkao [文獻通考]. For English translations, See Hucker, Charles. A Dictionary of Official Titles in Imperial China, p. 154; Zhang, Zhejun and Wang Jing. Song Dynasty Tales: A Guided Reader, p. 182n35.

18 Shi Jinbo, 1988, pp. 249, 253; “Xixia Shiqi de Wuwei” [西夏時期的武威] in Xixiaxue [西 夏學] (Tangut Studies) 7. Shanghai: Shanghai Ancient Works Publishing House, Dec. 2011. 
late Tangut history, Western Xia and the Jin Dynasty expanded their markets. In addition to the ones in Bao'an and Suide, a new market was added to the eastern end of the Hexi Corridor and in the Lanzhou prefecture, which at that time would have been under the administration and jurisdiction of the "Southern Realm" of Western Xia.

Most of the Tangut economic records mentioned in this book concern transactions within Western Xia. The corpus of Chinese documents, however, preserves a unique source of information on external trade: economic activities between the Tanguts and other people. These two collections of manuscripts are therefore complementary to one another. It also makes sense for the external trade records to be written in Chinese, as bilateral agreements are required to be written in the more commonly used language. A contract signed in Tangut is incomprehensible to Chinese partners, but a Chinese document is used beyond the territories of the Song Empire - such as in Xia to the west and Jin to the north. Chinese characters, therefore, played the role of lingua franca in business contracts throughout east, northeastern, and inner Asia. This is perhaps the reason why no inter-state market records in the Tangut language have been found up to this day. Whenever it comes to external trade, Chinese appears to have been the default language, thanks to its popularity and expediency. From another angle, this also demonstrates that even in the time when China was divided into ethnic regimes, the Chinese language persisted as a medium of economic and cultural exchange in the space between and across empires.

Exactly how these trade records made their way from Liangzhou to KharaKhoto is a question both worth asking and with no easy answer. Most of these documents are actually patched with the layering paper to the book cover of a Tangut block-printed Mahāvaipulya Buddhāvatamsaka Sūtra. It is very possible that the Khara-Khoto copy of Mahāvaipulya Buddhāvatamsaka Sütra originally came from Liangzhou. If so, one plausible explanation is that at the time when the sutra's cover was made in Liangzhou, a pile of papers was stacked together as a hard cardboard to provide physical support. Since paper was anything but in excess in Western Xia, those who made the book cover reused expired and long-discarded paper documents from the local market. In this way, these social texts travelled to Khara-Khoto with the sutra. Another hypothesis is that the sutra covers were instead fabricated in Khara-Khoto. This would mean that, since Khara-Khoto fell within the administrative authority of the larger Liangzhou-based government of the Northwestern Strategic and Regulatory Commission, used papers from Liangzhou markets were transported into various localities to be reused for printing purposes. The latter explanation, while certainly plausible, seems less likely to have been the case. 


\subsection{Records of Materials and Resources}

The editors of the Russian Collection of Khara-Khoto Manuscripts first designated a piece of manuscript dated to the second year of Qianyou as a "Timber Account." Upon closer scrutiny, however, we found several other types of materials and resources in the same document. Therefore, the document is now entitled "account of materials" or "record of resources."

1.2.1 Format and Content

A record of materials in the second year of Qianyou have been identified in manuscripts B61, Дх2828 and Дх10279 at the IOM. ${ }^{19}$ The three documents are each in 8,18 , and 4 fragments.

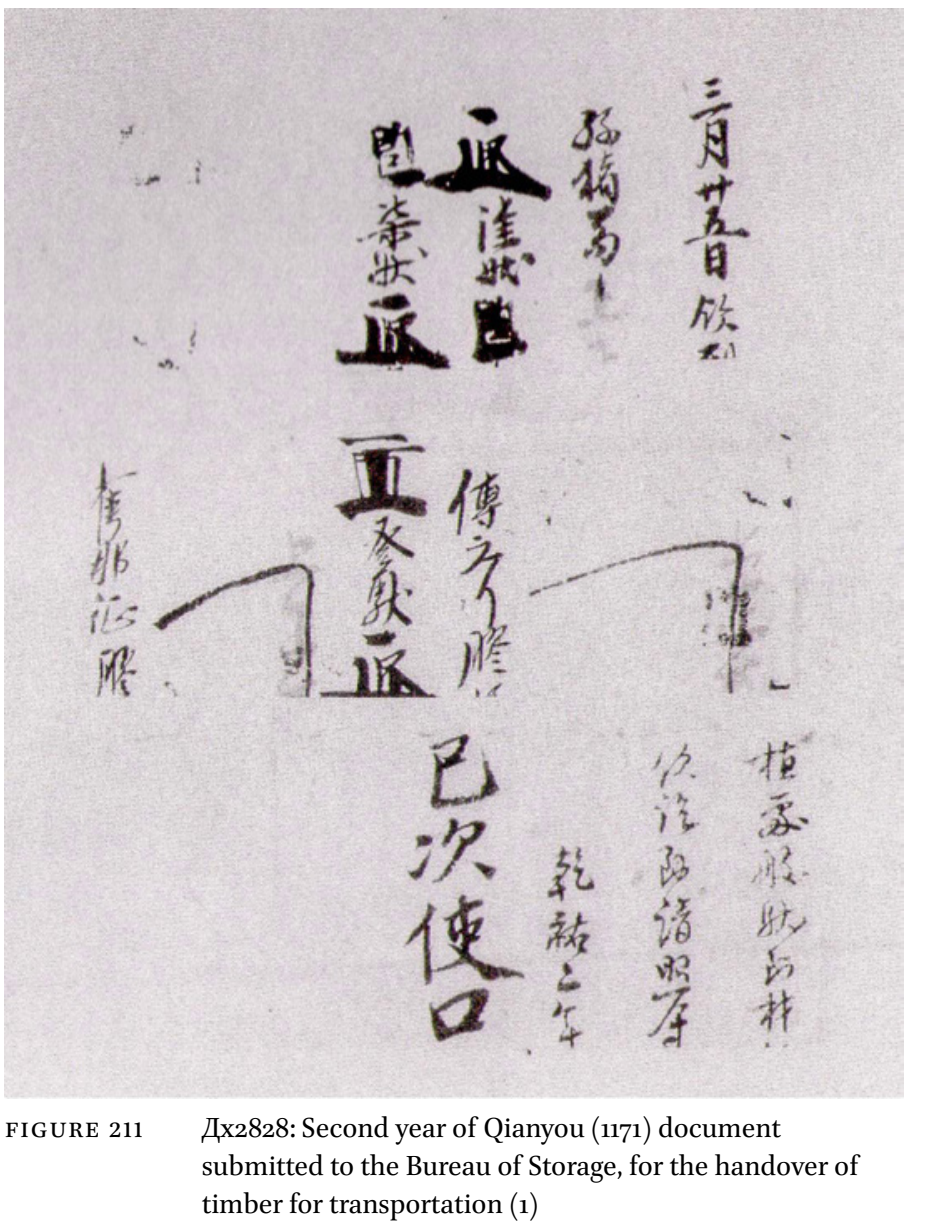


The following is a translated transcription of lines 1, 8, 12, 15, 16, 18 of Дх2828, and line 1 of Дx10279, which are the best preserved and the more legible parts of the manuscripts: ${ }^{20}$
$(1)$
... (signature, stamp) 2 loads (signature, stamp) ... ${ }^{21}$
... Wang Qinlai, sandy earth ...
... (signature, stamp) 2 loads (signature, stamp) ...
... (signature, stamp) 2 loads (signature, stamp), calendar ...
... Fu Chounu, sandy earth ...
... (signature, stamp) 2 loads (signature, stamp) ...
... (signature, stamp) 1 load (signature, stamp) ...
... Cui Nazheng, sandy earth ...
... (signature, stamp) 4 loads (signature, stamp) ...
... (signature, stamp) 4 loads (signature, stamp) ...

(8)

\section{Front page:}

... in Huaiyuan county cut ...

...2 pods, each weighs $4 \ldots$

... thousands

... each 14 chi long

...6 chi long, 1 chi wide ...

... month day $14 . .$.

20 See Sun, Jimin, et al. (eds.). Ecang Heishuicheng Hanwen Wenxian fei Fojiao Wenxian Zhengli yu Yanjiu [俄藏黑水城漢文文獻非佛教文獻整理與研究]: Compilation and Survey of non-Buddhist Han Chinese Documents in the Russian Collection of Khara-Khoto Manuscripts. Beijing: Beijing Normal University Press, 2012, vol. II, pp. 638-641, 662-671, 673-674. The title and the transcription are both based on the version published in that volume, where the first two documents are named "Document submitted to the warehouse office to request the hand-over of timber in the second year of Qianyou (1171) of Western Xia" (西夏乾祐二年付庫司文書為材植交納施行事), and the latter "Document submitted to the warehouse office for the hand-over of clay earth in the second year of Qianyou (1171) in Western Xia" (西夏乾祐二年付庫司文書為交納膠 泥土事).

21 TN: All the "loads" (䭾) in the translation refer to one unit load of goods onto a pack animal. 
Back (written between lines 3 and 4 on the front page):

... Officer who hand-received the submitted document: Yang Axi ... (12)

Front:

... $\square \square$ length: 14 chi ...

...4 chi, cun board, 2 pieces, each 6 chi long ...

...cun.

...5 materials, 2 pieces $\square$, 1 piece, length: 1 ? ... ${ }^{22}$

... $\square 5$ chi cun board, 5 pieces, each length: ...

... $\square$ material, 2 pieces, length: 14 chi each ...

... length 5 chi, width 1 chi 5 cun ...

... 2 pieces......

Back (written between lines $4-5$ on the front page):

... day 15, hand-receiver of the materials, Bai Bangou

(15)

Front:

Here, there is the footman Li Cai ...

Handover of timber sourced from ...

$\square$ 4 pieces for the purpose of building ...

According to the quantity to be delivered ...

1 load

$7 \times 5$ material 2 pieces $\ldots$

cun board, 4 pieces inside ...

2 pieces ...

1 piece, length: ...

$\cdots$

22 TN: This is a two-digit number. The number value of the single digit is missing. 
Back page: (written between lines 1-3 on the front page):

It is to Meng Ayong ...

zhiran ...23

(16)

Front page:

... right footman Li Zhu'er ...

... cut wooden board, 3 loads, each weighs ......

... on behalf of $\mathrm{Li}$, office of the warehouse, deliver ...

... load, $7 \times 5$ material, joint board, size ...

$\ldots 7 \times 5$ material 2 pieces, inside, 1 piece, length ...

15 chi long

... wooden board 2 pieces, each 6 chi long ...

... load, $7 \times 5$ material 2 pieces, inside ...

... 1 piece, length: 15 chi

4 pieces

Back of the page: (written between lines $2-3$ on the front page):

...... (signature, stamp) 2nd month, 12 th day received ...

(18)

Front page:

Right, request to the Warehouse, 2 loads of the above item ...

Timber, to proceed to provide. Second year of Qianyou ....... 2nd month, 17th day

...

23 TN: meaning of 只染... unclear due to the missing characters. It could be a term or a name, or yet a reference to the dyeing of the wood boards; or yet stamps and prints. 
ДХ1о279 (1) translated transcription:

...9 loads

5 loads (signature, stamp) 5 loads ...

... up 3 wan $^{24}$

... Shiban, load, claysmith ...25

...1 load (signature, stamp) 1 load (signature, stamp) 1...

... up 3 wan $^{26}$

... load clay earth ...

Both documents, B61 and Дx2828, are dated to the Renzong Emperor's reign, or the second year of Qianyou (1171). The B61 shows "second year of Qianyou, 25th day of 3 rd month" whereas the Дx2828 mentions the 2nd, 4th, 5 th, and 6th months in the second year of Qianyou. Both records refer to the county of Huaiyuan. The format, timing, and names of persons and places in B61, Дx2828, and Zx10279 suggest that they fit the same type of economic documents: written requests to the warehouse office that were necessary to receive an order of timber. The staff in charge of transferring and transporting the timber wrote down the quantity and quality of the timber in a given order and provided their stamps and signatures. The staff in charge of deliveries (manual labourers tasked with the actual move) also signed and stamped, but on the back of the page, noting down "received according to the number"; "received"; "already received," etc. The dispatchers and the delivery men each signed and stamped. Given this formality, these formal requests may be deemed as 'contracts.'

The 'sandy earth' (漫土) and the 'clay earth' (膠泥土) as mentioned in Дx10279 do not require stamps, signatures, or the acknowledgement of a receipt on the back of the page. One possible explanation is that these two types of materials required extraction on the part of the delivery staff, rather than a simple take-over from the warehouse. Regardless of the types of

24 TN: There does not seem to be a fitting translation for 上参丸, nor a consensus on its meaning. 丸 could of course be a unit of measurement, but I doubt if a small round object could be relevant to this context. Occasionally, 丸 does also substitute in for 完, that is, xxx goods 'uploaded' (hence the 'up'), where the loading is 'completed.' But that is my own uneducated guess.

25 TN: It is unclear how to punctuate or understand 示般䭾塑匠膠 without recovering more missing characters. Out of context, 示般 could only be considered a name of some sort. 䭾 is the regular unit of load, again without more contextual information. To me, 塑匠膠 is a claysmith or clay used for a smith's workshop or construction sites.

See TN on the previous occurrence of 上参丸. 
accounts and documents, all similar records have to do with the calculation of transportation and labour costs.

1.2 .2

The Tangut Economy of Transportation as Reflected in the Records of Materials

The manuscript fragment B61 (6) refers to the "Huaiyuan county" as an administrative region. The manuscript fragment $Д \mathrm{x} 2828$ (8) records that the materials are to be "delivered and handed over in the county of Huaiyuan." Of course, the history of Huaiyuan as a county goes back to the Tang Dynasty, when the area fell within the prefectural administration of Lingzhou. In the early period of Song Dynasty, Huaiyuan was downgraded to a town. But Li Deming "established a base in Huaiyuan, renamed Xingzhou," ${ }^{27}$ which Yuanhao remade into Xingqingfu, the legendary capital of the Tangut Empire. However, "Huaiyuan," as a name, did not fall into disuse. Rather, it remained used in popular languages in the imperial capital's vicinities but shifted to refer to an important county near the capital. The Tangut Laws of Heavenly Prosperity volume 10, "On the Order of Bureaus and Offices," for example, designated the four counties: Dingyuan, Huaiyuan, Linhe, and Baojing, along with Lingwu and Ganzhou as the Lower Bureaus. ${ }^{28}$ Both accounts of timber transportation mention Huaiyuan. These are processed, rather than raw timbers: 'ripe wood' or wooden boards of various sizes: " $7 \times 5$ " and " $4 \times 5$ " wood materials, or " 3 chi" and " 5 chi" cun boards, etc. Some are " 6 chi wide," others " 15 chi long" or "6 chi long, 1 chi wide," etc. In general, processed wood weighs less and are therefore easier to transport. Since the documents were found in Khara-Khoto, the timber might as well have been sourced from local areas. These wood materials could have been made from a special kind of timber in the Khara-Khoto area. When the imperial government lays out plans for constructions, they would request that these processed timbers be transported to the vicinities of the capital, such as the Huaiyuan county, for use at construction sites.

The manuscript fragment Дx2828 makes repeated mentions of "footmen." ${ }^{29}$ As intuition may suggest, these were transport workers, a profession documented at length in chronicles of the Five Dynasties, Song, and Yuan Dynasties. ${ }^{30}$ Names shown on transport records show Sun, Fu, Cui, Wang, Yang, Li, He, Liang, Tian, Bai, and Meng. The all-Chinese team suggests that

27 History of Song, Bk. 485 "The State of Xia" Part I.

28 Revised Laws of Heavenly Prosperity, vol. 10, "The Order of Bureaus and Offices," p. 363; see Shi and Li, p. 449 .

$29 \mathrm{TN}$ : 腳戶, 腳家, or 腳人.

30 Old History of the Five Dynasties, Bk. 146, "On Food and Trade"; History of Song, Bk. 271, "Biography of Guo Tingwei"; Song, Lian; Zhao, Xun; Wang, Yi, et al. Yuanshi [元史] History of Yuan. Beijing: Zhonghua Book Company, 1976. Bk. 93, "On Food and Trade." 
most Tangut 'footmen' in the business of long-distance transportation were Han-Chinese ethnics. Perhaps because of this oversized representation in the profession and for the sake of expediency, these documents were written in Chinese only. This way, it was easier for the officials to communicate with the Han Chinese 'footmen' and for the workers to sign and stamp, without extra logistical costs and problems that may arise from language barriers.

\subsection{Hay Account}

There is also a number of economic records in the British collection of Khara-Khoto manuscripts, amongst which are four pieces of hay (for the horses). These documents shed light on the conditions of hay supplies and horse provisions in Western Xia.

1.3.1 Format and Content of Hay Accounts

All four pieces of hay records were originally unearthed in Khara-Khoto. For a long time, they were preserved in the midst of fragments in the Or.1238o-3178 manuscripts. ${ }^{31}$

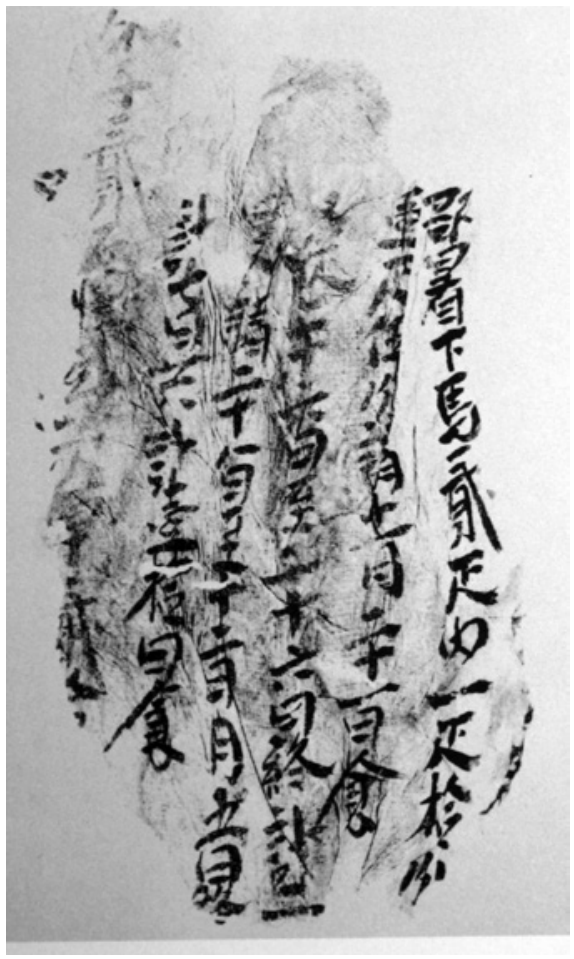

FIGURE 212

British Manuscript Or.1238o-3178a (K.K.):

Hay account 
1. British manuscript Or.1238o-3178a (K.K.): Hay Account:

For the staff arranged ${ }^{32}$ horses 2 pi, of which $1 \mathrm{pi}$ [of horse] is granted 10 points [worth of ration]

$\square$ 1 [another] pi [of horse] 5 points [worth of ration] $\square$ 11th month, 21st day, food

From 26th day, to 26 th day, end. Counted: $1 . .$.

... request: 28 th day, to 12 th month 5 th day, end.

Counted 7 days, in total $\square$ food for 10 days

... $\square \square$ dan ...

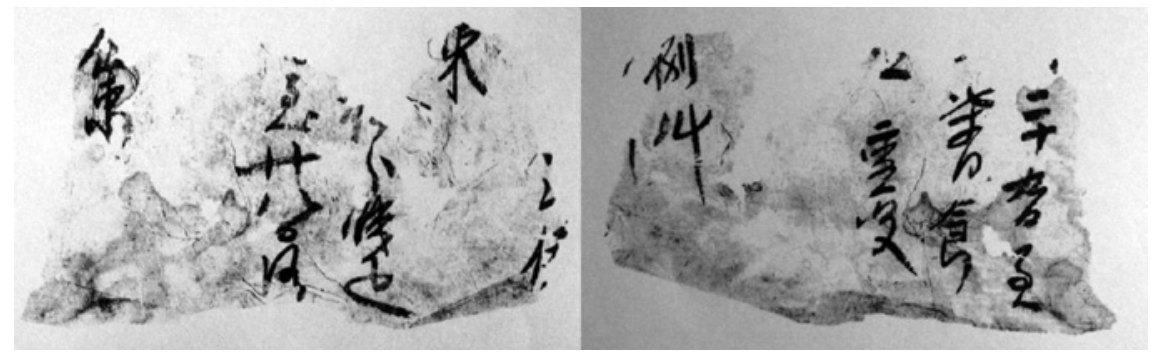

FIGURE 213 British Manuscript Or.1238o-3178b (K.K.): Hay account

2. British manuscript Or.1238o-3178b (K.K.): Hay Account:

... bundle

... $\square 4$ pi

... till day 28 , end

... $\square$ bundle

... day 29 , till

... food for 7 days

...

... 8 dou ... 


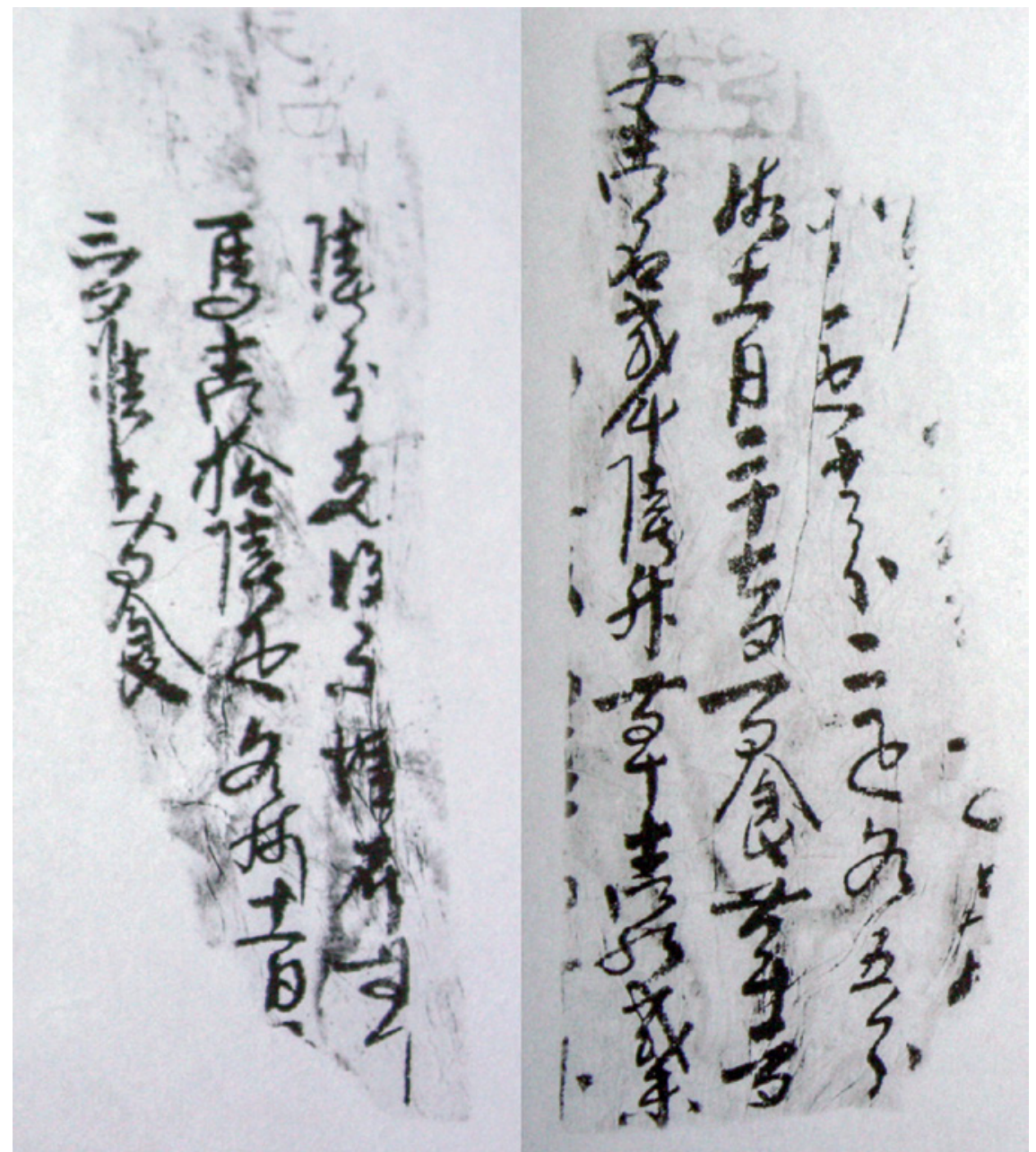

FIGURE 214 British Manuscript Or.1238o-3178c (K.K.): Hay account

3. British manuscript Or.1238o-3178c (K.K.): Account of Hay (for horses):

6 points, provided $\square \square \square \square$ hay

Horses 16 pi, each provided for 11 days ...

3 days, ration for 20 days

... 1 pi [of horse] 10 points [worth of hay]; 2 pi [of horse] 5 points [worth of ration] each

(on) 11th month, 27th day, hay for one day's provision, 2 days

... zi 1 dan 2 dou 6 sheng, hay 12 bundles 


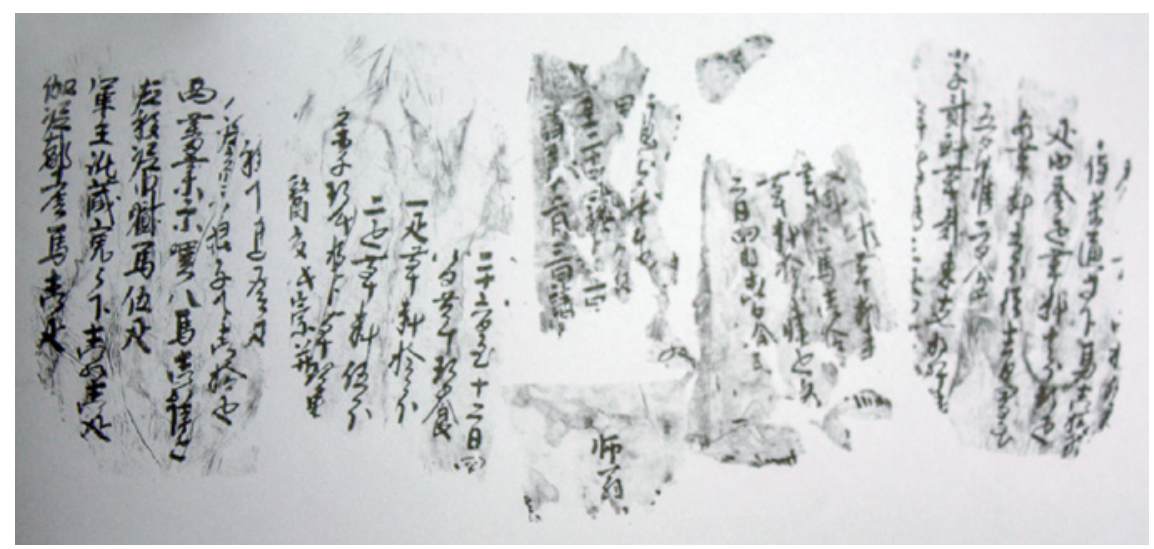

FIGURE 215 British Manuscript Or.1238o-3179 (K.K.): Hay account

4. British manuscript Or.1238o-3179 (K.K.): Hay Account:

... Bao $\square$ tong et al., horses 12

$p i$, including 10 points [worth of] hay for $3 p i, 9 p i$

Each 5 points [worth of] hay, must 12th month 4th day to $5^{\text {th day, }} \square$ approved standard food for 2 days

$\square$ (proso millet) 2 dou, hay 2 bundles, provide $\square \square \square$...

... $\square \square[$ [horses 3 pi] ...

$\square$ hay 8 bundles ...

... hay, $\square$ horses 10 ... 33

... hay/forage, 14 pi, each ...

Month 2, day 4, food for one day

To 2 oth day ...

Request, to 12 th month 3 rd day request ...

26th day to 12 th month 4 ...

Hays for 8 days, food for 9 days

First pi [of horse], hay 10 points [worth of ration]

Second $p i$ [of horse]: hay 5 points [worth of ration]

Proso millet, 9 dou $\square \square$, hay 9 bundles

…

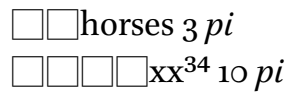


$\mathrm{Xi} \square \square$ shiluoba, horses 16 pi

Zuoyi Nijinni, horses $5 p i$

Military officer Ezang Weiming, 11 pi

Ganidu $\square$ horse $1 p i$

\subsubsection{Analysis of Hay Records}

Of the documents above, the British manuscript or.12380-3179 (K.K.) is the richest in content. It even lists the names and positions of the persons involved: "Zuoyi Nijinni, horses 5 pi"; "Under military officer Ezang Weiming, $11 p i$ [horses]"; "Ganidu $\square$, horse 1 pi" etc. Chinese chronicles often mention certain Tangut 'army leaders' [軍主], which is certainly a military office in Western Xia. ${ }^{35}$ The names of the concerned parties in the documents, such as Ezang, Zuoyi, Gani, and especially Weiming and Ezang, were prominent Dangxiang Tangut surnames. There is no question, even from the content itself, that these records are from the Tangut era.

From the incomplete records above, it is easy to tell that the Tanguts made active distinctions between different horses, providing them with different amounts of hay based on points of five or ten. The Tanguts also supplied horse provisions based on the number of days on a given business trip: 1 day, 2 days, 3 days, 7 days, or up to 20 days. This criterion seems to suggest that the documents were used for the horse provisions of government employees dispatched on official duties. It is illuminating to compare the actual records with the relevant statements in the Laws of Heavenly Prosperity. It describes when and where the Court dispatches officers on horses to state-owned pasturing lands for the examination of government-owned livestock:

The officers sent out from the imperial capital to review and examine the many pasture lands, including the clerks (antou), office staffs (sili), attendants, as well as juniors acting in the capacity of servants, may procure rations of food for their horses from the government. When they receive the provisions from the pastures, let the precise numbers be calculated, and let anyone be judged and duly prosecuted for any violation of the laws.

A senior officer enjoys 1 slaughter every 7 days, and 4 sheng of rice and flour each day, including 1 sheng of rice; of the two horses, one is

35 History of Song vol. 5, Chapter II on Taizong Emperor, 485: Book on the State of Xia; 7: chapter II on Zhenzong Emperor; 492: Book on the Dangxiang. 
provided with 7 sheng, the other 5 sheng. One junior servant receives 1 sheng of rice.

Together, the Antou and the Sili enjoy a slaughter every 15 days; each receives 1 sheng of rice per day; their horse is provided with 5 sheng of food.

One Keeper of the Rod is allotted 1 sheng of rice per day.

One examiner enjoys a slaughter every 15 days, 2 sheng of rice and flour per day; his horse is allotted 5 sheng. ${ }^{36}$

The Tanguts also laid down exhaustive rules on the allotment of hay to government employees dispatched on horses on official trips:

Provisions to the staff in the Bureaus of Review and Inspection, according to their ranks:

A Senior Official enjoys a slaughter every 10 days, 4 sheng of rice or grains per day; of the 2 horses, each one is allocated 7 sheng, the other 5 sheng; a Junior is allotted 1 sheng of rice.

An official such as a Secretary in the Bureau of Review and Censorship each enjoys a slaughter every 15 days, 1 sheng of rice per day; 5 sheng for the horse; a Junior is allotted 1 sheng of rice per day.

Government employees: Antou and Sili both enjoy one slaughter every 20 days; each of them is allotted 1 sheng of rice per day; a Junior and a Keeper of the Rod each has 1 sheng of rice.

Provisions granted to the employees in the higher and lower Bureaus of Livestock Review and Inspection, according to ranks:

A senior official enjoys a slaughter every 7 days, 4 sheng of rice or grains per day, of which there is 1 sheng of rice; food for 4 horses, 7 sheng for one horse, 5 sheng in case of the 3 horses; for the three children, there is 1 sheng of rice per day.

$3^{6} \quad$ Revised Laws of Heavenly Prosperity 19, "On the Examination of Livestock," p. 585. 
All serving agents in the Bureau of Review and Inspection and others enjoy a slaughter every 15 days, 1 sheng of rice per day, 5 sheng of food supply to the horse, as well as 1 sheng of rice to a single child.

The two lower-level Antou and Sili officials enjoy a slaughter every 15 days; to each of them, there is a supply of horse food in 5 sheng; to each of them there is 1 sheng of rice per day; to the one child, there is 1 sheng of rice.

Each of the two men receives an allocation of 1 sheng of rice per day:

One in charge of the rod.

One in charge of equipment. ${ }^{37}$

In the Laws of Heavenly Prosperity, rules on the provisions of meat, grains, and hay to government staff and their retinue (including horses) on official trips are extensive and exhaustive. The Chinese documents transcribed, translated, and discussed above have not only verified the information we find in the law code but also add new insights on the enforcement of the laws. We now know, for example, that the provision of hay had to be approved, according to the different ranks of horses. The quantity of hay is calculated according to the duration of the trip (in days) and again recounted in summary statistics. It is a slight pity, however, that these documents refer only to the allotment of hay for horses, not that of food and meat to the officers and staff.

2

\section{Contracts}

Though fewer than Tangut contracts, Chinese contracts in Western Xia are just as diverse and valuable historical sources and economic records.

\subsection{Grain Loan Contracts}

Several Chinese grain loan contracts were discovered in Khara-Khoto and seized by both Kozlov and Stein. These contracts were written on fragments that were used as layering papers of Buddhist sutras. A businessman named Pei Songshou, apparently active in the pawning business, is the protagonist in these contracts. In 1953, Henri Maspero published The Chinese Documents of the Third Expedition of Sir Aurel Stein in Central Asia in London, which

37 Revised Laws of Heavenly Prosperity xx, "On the Different Degrees of Crimes and Liabilities," pp. 613-614. 
contains the Tianqing grain pawning contracts of Western Xia. ${ }^{38}$ The contract is included in Dunhuang Ziliao issue 1, edited by the Institute for History at the Chinese Academy of Social Sciences and published in $1961 .{ }^{39}$ In 1980, Chen Guocan published an article on the subject, "A Restoration of the Grain-Pawning Contracts Fragment in the Tianqing era of Western Xia," based on the material presented in Dunhuang Ziliao. What he accomplished was a close examination and interpretation of the 15 pawning Tianqing contracts at the British Library. ${ }^{40}$

Grain-pawning contracts, also dated to the Tianqing era of Western Xia but obtained and preserved by the Russians at the Iом, came into public light in the 199os, as Chinese and Russian experts collaborated on the publication of the Russian Collection of Khara-Khoto Manuscripts (photocopy in Vol. 2).41 Although the English and Russian manuscripts are from the same period and concern the same Pei Songshou, the grains loaned and the interest rates applied are quite different.

Amongst the 15 documents held at the British Museum, 11 have survived well and remain legible. The first piece, in particular, offers an abundance of evidence:

Tianqing 11th year, $5^{\text {th }}$ month 3 rd day, contract set by Wunü Langsu presently ...

... $\square$ fur coat 1 item, from Pei's place ...

... dou plus 3 (interest), wheat 5 dou plus 4 (interest), principle \& interest total, barley ...

... dou 5 sheng, if pawn not redeemed, till the due time the coming August ...

Let sold, no complaint.

Contract set by Wunü Langsu (stamped)

Witness $\square \square$ (stamped)

In the light of a comparative analysis with the other 14 contracts, as well as further research and inference, Chen Guocan has surmised some of the

38 TN: French sinologist and philologist Henri Maspero (1883-1945). See, Maspero, Henri (eds.). Les Documents chinois de la troisième expédition de Sir Aurel Stein en Asie centrale, London: British Museum, 1953.

39 For the original, see Chinese Academy of Social Sciences-Institute for History (eds.). Dunhuang Ziliao [敦煌資料]: Sources of Dunhuang, issue 1. Beijing: Zhonghua Book Company [中華書局], 1961.

40 Chen Guocan, 1980.

41 Russian Collection of Khara-Khoto Manuscripts, vol. 2, pp. 37-38. 
missing characters and filled in the incomplete information. The following is his amended version of the contract:

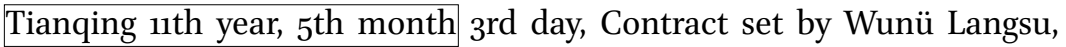
who presently, with her own $\square \square$ fur coat 1 item, at Pei's place pawned in exchange for wheat 5 dou, plus 3 as interest; wheat 5 dou plus 4 as interest; principle \& interest: 1 dan 3 dou 5 sheng of barley. If the pawn is not redeemed by the due date: 1 st day of the 8 th month, then let [the fur coat] be sold, and let there be no complaint or dispute.

Contractor: Wunü Langsu (stamped)

Witness: Ejing (stamped)

The contract tells the story of a woman who has to pawn her belongings in exchange for subsistence. To pawn fur carpets or fur coats for grains, the interest rate was usually $30 \%$ or $40 \%$ for three months. If one takes into account the fact that, in most cases, the possession was under-valued by the pawning shop, then the interest rate might as well be around $50 \%$, roughly the equivalent of the rates found in Tangut grain loan contracts.

In the Russian Collection of Khara-Khoto Manuscripts, there are 12 pagefragments, registered as TK49P. They are contracts signed by borrowers of grain and by the aforementioned loaner, Pei Songshou in a year of Tianqing. Amongst them, the data in five pieces of contracts remain legible.

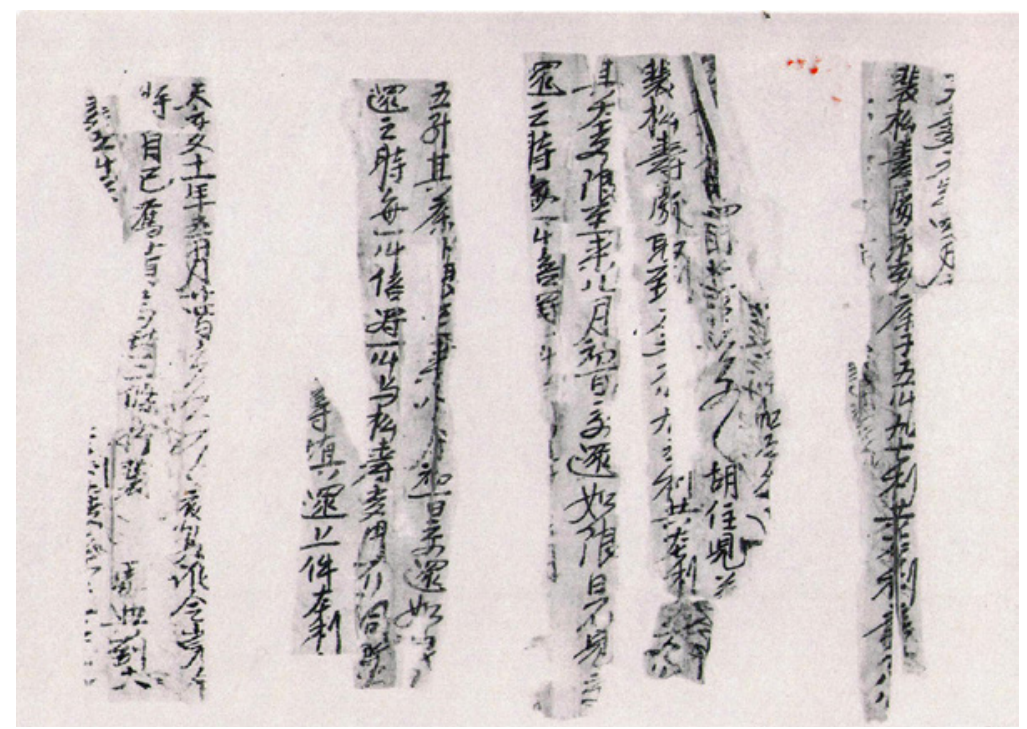

FIGURE 216 Russian Khara-Khoto manuscript TK49P: Tianqing contract of pawning wheat at Pei Songshou's place 
The following is a translated transcription of one of these contracts:

On the 16th day of the 4th month in the 6th year of Tianqing, contractor Hu Zhu'er $\square$...

From the place of Pei Songshou, obtained barley in the amount of 6 dou, plus 5 as interest; the principle and interest in total are $9 \mathrm{dou}$,

The loan of barley is due to be repaid by the 1st day of the 8th month. If by the due date it is not

Repaid, let there be 1 dou of penalty per dou of loan ...

It is not clear what kind of property is being pawned, except that it is worth approximately 6 dou of barley. "Plus 5 as interest" means a " $50 \%$ interest rate." With a total of 11 pawning contracts signed anytime between the 1st and the 9th day of the $5^{\text {th }}$ month in that year, Pei Songshou loaned out wheat and barley in a total amount of 14 dan. Pei was in the pawning business at least from the 6th year (1199) to the 11th year (1204) of Tianqing. He charged exorbitant interest rates during these six years: $50 \%$ interest rate in the 6th year of Tianqing, $30 \%$ or $40 \%$ in the 11th year of Tianqing, etc. All of these pawning arrangements count as usuries. He counted on loans to people who would pawn their clothing in the 4 th or $5^{\text {th }}$ months of the year, when there was no longer the need for heavy coats to survive the wintry days. However, it was also a time when leftover grains from the previous year ran out, and new crops were not yet ripe for harvest. The plan was to redeem the pawned properties, albeit at the cost of additional interests, after the harvest. These contracts show the exploitations of the poor at the hands of usurious loaners. It seems that, at least in Khara-Khoto but probably also elsewhere in Western Xia, there existed a class of professional financiers such as Pei Songshou who profited mostly, if not only, from usuries. ${ }^{42}$ They issue grain loans in exchange for pawned properties and high interests. It is a peculiar profession in Tangut society and economy.

Pei Songshou arranges for multiple pawning contracts to be written and signed in continuum on the same piece of paper. This format is present in some of the Tangut grain loan contracts, as well. ${ }^{43}$ Although squeezed into one single account, each document features the signatures and stamps of its own borrowers and witnesses. So, there is no question that, in terms of legal force, each of them counts as a contract in the proper and accurate sense of the term.

\footnotetext{
42 Du, Jianlu. “Heicheng Chutu de Jijian Hanwen Xixia Wenshu Kaoshi” [黑城出土的幾 件漢文西夏文書考釋]: “A Critical Interpretation of Several Chinese documents of Western Xia Unearthed in Khara-Khoto" in Zhongguoshi Yanjiu [中國史研究]:Journal of Chinese Historical Studies, issue 4, 2008.

Shi Jinbo, 2005 (b).
} 


\subsection{Monetary Loan Contracts}

There is a total of three Tangut monetary loan contracts written in Chinese, all preserved at the гом of the Russian Academy of Sciences: the Инв. No. 7779 A, the Инв. No. 7779 B, and the Инв. No. 7779 E. All three are contract fragments, originally written on layer papers of the Tangut Buddhist sutra Mahāmāyūri-vidyārājiñ - sūtra. ${ }^{44,45}$ The $7779 \mathrm{~A}$ is cut into two fragments, each $9.6 \mathrm{~cm} \times 29.7 \mathrm{~cm}$. At the joint of the two fragments, half a character is missing. But there is no question when it comes to dating the contract: " $\square$ sheng Guiwei $15^{\text {th }}$ year" - obviously it should have been "Guiwei the 15th Year of Tiansheng" (1163 AD). On the back of the cover is a balance sheet account, with statements of incomes and expenditures. The $7779 \mathrm{~B}$ contract has survived in three separate fragments: (1) $11.2 \mathrm{~cm} \times 7 \mathrm{~cm}$, also dated to "Guiwei 15th Year of Tiansheng" (2) $19.1 \mathrm{~cm} \times 4.6 \mathrm{~cm}$, with the following note: "received on the 8th day, now with money in the amount of 5 guan wen" etc. (3) $19.3 \times 5.8 \mathrm{~cm}$, with references to "the person who set up the contract" etc. The $7779 \mathrm{E}$ contract is $9.6 \mathrm{~cm} \times 7.8 \mathrm{~cm}$, with a note that reads, " 20 wen, to be fully [repaid/reimbursed] in 65 nights" etc.

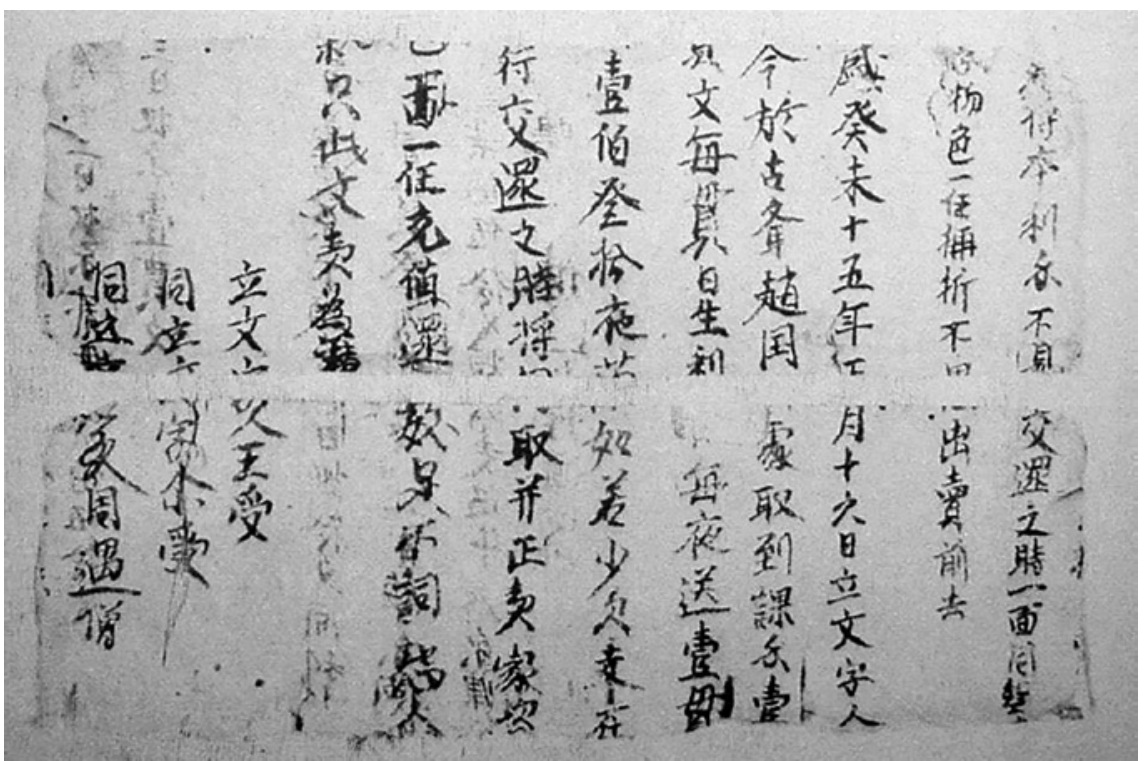

FIGURE 217 Инв. No. 7779A: 15th year of Tiansheng (1163) Wang Shou's contract of monetary loan

44 Russian Collection of Khara-Khoto Manuscripts, vol. 6, pp. 321, 322, 325 .

45 TN: See Shi and Li, p. 113. Tibetan title: Rig-snags-kyi rgyal-mo rma-bya chen-mo. 
The Инв. No. $7779 A$ is mostly intact and legible. The following is a translated transcription: (the contract begins with the 3 rd line as shown in the image):

... Tiansheng era, Guiwei 15th year, 1stmonth, 16 th day, contractor ...

... present, from "ancient Qi \& Zhao states" $\square$ place, received monetary loan $1 . .$.

...... guan wen, each guan at the interest rate of $\square, 1$ guan to be delivered per night ...

......130 nights completed[payment]; in case of insufficient repayment, at ...

the time of repayment, will also obtain the contract, household property $\ldots$

suffer confiscation as repayment, until the debt is cleared, with no complaint. lest ......

... This contract alone serves as testimony.

Contractor: Wang Shou

Co-Contractor:Xiaoshou

Co-Contractor: Zhou Yuseng ...46

The manuscript Инв. No. $7779 A$ provides the date, month, and year of the contract, the names of the borrowers and the creditor, the size of the monetary loan, terms, interest rates, and penalties in case of default. The contractor (borrower) and the co-contractors (guarantors) all signed but did not stamp the contract. The first two lines, as it appears on the contract, are the ending of a previous contract, which seems to be incomplete and without the proper signatures of names. Given a number of suspicious evidences, the creditor is bizarrely referred to as the "ancient Qi \& Zhao states," the loan is in a large quantity, and the borrower is to 'deliver 1 guan of interest per night.' The document thus does not seem to be a normal contract and might have been a special kind of document that was written in the contract format.

\subsection{Lease Contracts}

There is a remarkable piece of contract in the Russian collection of Khara-Khoto manuscripts, the Дx18993 contract of bakery shop lease in the 1st month of the 12th year of Guangding, signed by Li Chungou et al. At first, the document was not given a title, and was placed by mistake in the Russian collection of

46 For the transcription, see Compilation and Survey of Non-Buddhist Han Chinese Documents in the Russian Collection of Khara-Khoto Manuscripts, vol. II, p. 749. 
Dunhuang manuscripts, and included in the published edition of the Russian Collection of Dunhuang Manuscripts vol. 17, p. 310. ${ }^{47}$ The 12th year of Guangding (1222) fell within the reign of Shenzong emperor, Li Zunxu, near the twilight of the Tangut Empire.

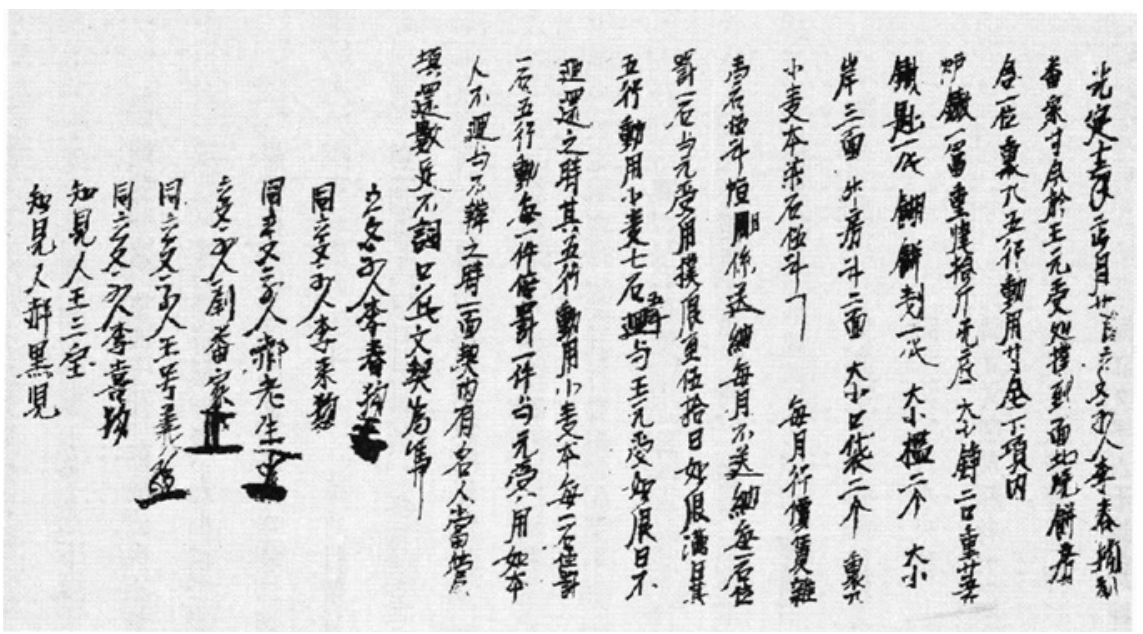

FIGURE 218 Дx18993: First Month, 12th year of Guangding (1222) Li Chungou, et al., lease contract of renting a house for baking pancakes

Translated transcription:

In the 12th year of Guangding, on the 21st day of the 1st month, Contractor Li Chungou, Liu

Fanjia, et al., presently received from Wang Yuanshou north-faced flatbread house

One lot, li jiu wu tools all equipped, ${ }^{48}$ the following items

47 Institute of Oriental Manuscripts (Іом), Russian Academy of Sciences in St. Petersburg (Институ́т востокове́дения Росси́йской акаде́мии нау́к, Санкт-Петербургское отделение) \& Shanghai Ancient Works Publishing House (eds.) Ecang Dunhuang Wenxian [ 俄藏敦煌文獻]: Russian Collection of Dunhuang Manuscripts, vol. 17, p. 310. Shanghai: Shanghai Ancient Works Publishing House, 2001.

$48 \mathrm{TN}$ : 裏九五 could be referring to the size of the shop, or to the tools therein equipped. 行 動用 or 動用 definitely refer to the tools to be used. A discussion with Professor Du Jianlu has left it as an open-ended question. 
Griddle 1 item, weighs 40 jin, no bottom [of pot]. Large and small toasters $2 ;^{49}$ weighs 25 jin.

Iron spoon 1, Spatula 1,50 large and small cupboards $2,{ }^{51}$ large and small [cutting] boards $3{ }^{52}$

Boards 3 , shengfangdou $2,{ }^{53}$ large and small bags 2 , li jiu

Wheat and principle, 7 dan 5 dou; miscellaneous rents on a monthly basis 1 dan 5 dou of monthly payment. If the monthly rent is not delivered, for each dan, there is a

dan of penalty, for the use of Yuanshou. When the lease is due in $5^{\circ}$ days, by due date, its

5 tools are used, wheat 7 dan 5 dou, to be paid back to Wang Yuanshou. When due, if it is not

returned, and if the 5 tools are used, then a penalty of 1 dan of wheat applies to each loan of

1 dan; each of the 5 tools $^{54}$ is penalised with a new one for Yuanshou's use. If the person

himself does not return or cannot be identified, the co-signed parties in the contract ought to

fill in the full sum, without complaint. Let this contract alone be the proof.

Contractor: Li Chungou [stamped]

Co-Contractor: Li Laigou

Co-Contractor: Hao Laosheng [stamped]

Contractor: Liu Fanjia [stamped]

Co-Contractor: Wang Haoyi [stamped]

Co-Contractor: Li Xigou

Witness: Wang Sanbao

Witness: Hao Heijian

This is a rare piece of a fully complete contract, and rare also with regard to the type of contract: a contract of bakery shop lease. It is the only survived

49 TN: 鋝 is a generic, alternative reference to 餅鐺. Not the electric type, of course, but metal pans used to fry and bake cakes.

5O TN: I am somewhat confident that 餬餅划 refers to a specialised spatula used for lifting and flipping shaobing.

$5^{1} \quad \mathrm{TN}$ : The 檻 here most probably refers to cupboard or a case.

52 TN: a wild if not impossible guess is that these are cutting boards.

$53 \mathrm{TN}$ : The 升房斗 is a measure container of a dou, in which there is an attached container that measures a sheng.

54 TN: I would fill in "the [damage of] each ..." 
contract of shaobing shop lease from Western Xia. It may be either singular, or 'as uncommon as the phoenix's feather and the unicorn's horn' in the entire history of Chinese contracts.

The contract's reference to "wheat and principle: 7 dan 5 dou" may be the summary principle that includes both the shop itself and the tools that are included in the lease. The interest is calculated based on this total sum of principle. Therefore, the rent: " 1 dan 5 dou of monthly payment" is basically a monthly interest charged on the principle in the amount of " 7 dan 5 dou." It amounts to a monthly interest rate of $20 \%$. A 5 -month lease would yield the creditor a cumulative interest rate of $100 \%$; the rate for a one-year lease would rise up to $240 \%$. We know from the vast number of Tangut grain loan contracts that although some of the interest rates reach up to $100 \%$, most stay around $50 \%$ for a duration of three to six months. Therefore, if the agreement between $\mathrm{Li}$ and Wang is representative of Tangut shop leases in general, then one could say that the loan of bakery shops charges a much higher interest rate than that of grains. But one would expect this to be the case, given that the shaobing shop is a for-profit enterprise rather than a source of simple subsistence. ${ }^{55}$

\section{$2.4 \quad$ Land Sale Contracts}

In the 199os, experts from the Dunhuang Academy systematically surveyed the stone caves in the northern zone of the Mogao Grottoes. Amongst their discoveries were a batch of Tangut and Chinese manuscripts dated to the era of Western Xia. One of the Chinese documents is the G11 • o31[B59:1] manuscript found in the 59 th cave in the northern zone: land sale contract by Weiming Fabaoda. ${ }^{56}$ The manuscript fragment is $18.8 \mathrm{~cm} \times 22.7 \mathrm{~cm}$ in size, contains 11 lines of texts, and features four red seals, two of which remain legible.

55 Du Jianlu and Shi Jinbo, 2010 \& 2012, pp. 42-48.

$5^{6}$ Chinese Collection of Tan $[U+o o B 7$, Brill font $]$ ut Manuscripts, vol. 16, p. 46. 


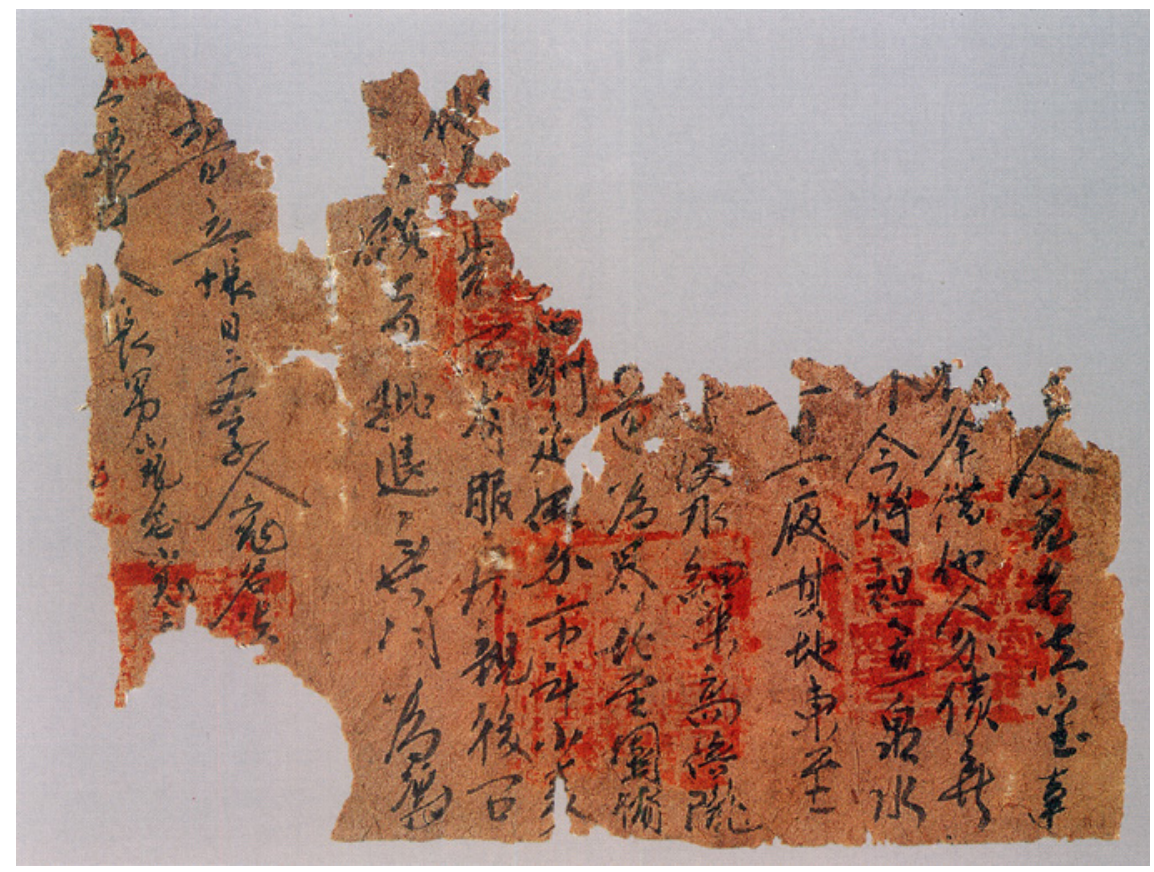

FIGURE 219 Mogao Cave, G11 • o31 [B59:1]: Weiming Fabaoda land sale contract

The following is a transcription of the main text of the document: ${ }^{57}$

... year, setting the account in text person, Weiming Fabaoda

... due to the difficulty and poverty of life? borrow loans from others, no thing to repay? ... $\square$ now, to have [on the] plain $\square$ straight-flowing spring (water)

... one day, one night, the land's east end-point

... $\square$ makes the water narrow streams on Gaobeilong

... way, as boundaries, bi (north) up to the yard

... $\square$ to negotiate on the premise of market price of wheat

... the land unsold? others, first ask the relatives of the same house, then ask the

57 For the transcription, see Luo, Haishan. “Weiming Fabaoda Maidi Wenshu Kaobian” [嵬名 法寶達賣地文書考辨]:“A Critical Study of the “Weiming Fabaoda Land Sale Document” published in Shen, Zhibei. San Ge U Ji: Huo Cunfu Jiaoshou Congjiao Sanshinian Jinian Wenji [3 個U 集: 霍存福教授從教三十年紀念文集]: Three Us: Collection of Essays in Honour of Professor Huo Fucun's Thirtieth Year of Teaching. Beijing: Intellectual Property Publishing House Co., Ltd, 2015. 
neighbours, unwilling ones rescind, $\square \square$ have $\square$

... 1st day, contractor Weiming $\mathrm{Fa}$ [baoda]

... co-contractor of the account, elder son, Weiming $\mathrm{We} \square$

This contract fragment on the sale of land features four seal prints in the red colour. The seller of land, namely the "person who sets up the account in text" is listed as Weiming Fabaoda. It is no secret that the Weimings were a large royal family of the Dangxiang Tanguts. It is all the more intriguing then that the purpose of the sale was to compensate for "personal debts of monetary loans from others." Interest rates in Western Xia were notoriously high. ${ }^{58}$ The feudal regime assumes as one of its primary duties the guaranteed protection of the interests of the creditors. The laws require that "let all demand and press the debtors for repayments, the failures of which are to be reported to the bureau, in order that force be employed to search, obtain, and interrogate."59 After its occupation of Dunhuang, the Tangut regime inherited the irrigation system from the Tang and Five Dynasties. References to "springs" and "narrow canals" as endpoints of the region for sale in the contract fragment prove the existence of irrigations in neighbouring areas. By the rule "first ask the relatives in the family, then inquire the neighbours" this legal document affirms what we know to be conventional rights of families and neighbours.

Although a page fragment, this document has gained the attention of a number of Tangutologists and have been subject to many critical surveys. These scholars, however, diverge in their naming, timing, and determination of its properties. Since this document mentions neither names of buyers nor terms of default penalties and also uses the word for 'account' rather than 'contract,' some experts have named it "Account of Land Sale by Weiming Fabaoda." For others, a careful analysis of the format and other aspects of this contract suggests that it might have been a land sale contract by the Tanguts after the fall of the regime, possibly during the Yuan Dynasty years. ${ }^{60}$

58 Du, Jianlu: “Xixia Gaolidai Chutan” [西夏高利貸初探]: “A Preliminary Survey of High Interest Rates in Western Xia” in Minzu Yanjiu [民族研究]: Ethno-National Studies, issue 2, 1999; Shi Jinbo, 2005 (b).

59 Revised Laws of Heavenly Prosperity, vol. 3. "On Urging the Payment of Debt."

6o Luo, Haishan. “Weiming Fabaoda Maidi Wenshu Yanjiu” [嵬名法寶達賣地文書研究]:

"A Study on the Document of Weiming Fabaoda's Sale of Land" (unpublished paper). 